\title{
Comedy writing as method: reflections on screenwriting in creative practice research
}

Craig Batty, University of Technology Sydney

Stayci Taylor, RMIT University

\begin{abstract}
Comedy writers use their practice to raise questions and create awareness about social, political and cultural issues, but can these practitioners be considered academics? With creative modalities of enquiry now commonplace in universities where research is used to shape one's practice, resulting in creative work that embodies that research - when does comedy writing start to take on a different function? In this article, we discuss comedy screenwriting in an academic setting, arguing that it has potential as a rigorous mode of research that can sit happily alongside art, design, creative writing and media practice. Much has been written about creative practice research, yet not so much has been written about the form this type of research takes; specifically, why one might choose comedy to express, embody or otherwise perform the findings of research. Here, then, we draw on our experiences of undertaking screenwriting projects using comedy to discuss the ways in which researchers might use the comic mode to present their findings in imaginative, innovative and fun ways that can expand understanding and, potentially, garner impact.
\end{abstract}

\section{Key words}

Comedy; fiction; screenwriting; screenplay; creative practice research; methodology

\section{Introduction}

In an organic café in Adelaide's East End, a $\mathrm{PhD}$ examiner opens a package of documents. The screenplay, Bothering Heights, is a ten-part sitcom set in a commission flat tower in Melbourne's inner north. The dramatic stakes are high, and the language is foul. As she sips her turmeric latte, the examiner is intrigued to read the research abstract: 'This $\mathrm{PhD}$ draws on sociolinguistic analysis to argue for the importance of the semi-colon in post-Snapchat Australian vernacular.' According to the candidate, the $\mathrm{PhD}$ uses a screenwriting practice methodology to 'do' this 
research, wherein the sitcom provides a creative way of understanding - and feeling the research findings, in particular via the use of communal dialogue.

Though perhaps an extreme example of a PhD that will most likely never though technically could - be produced, this scenario highlights the premise of our article: that in the literature on creative practice research, we seem to have neglected discussion of the form or genre in which we work, instead more concerned with defining and defending research methodologies, and ensuring that creative work and dissertation/exegesis form a coherent scholarly argument. For us here, put simply, why comedy? What can fictional funny scenarios offer to academic research that other forms or genres might not?

As a note on research terminology and methodology, here we are concerned with what might be called practice-based research, or research-led practice (Smith and Dean 2009), as opposed to practice-led research or those phrases that privilege process as the contribution to knowledge, not necessarily the creative work as a research output that contains, embodies or performs knowledge in its own right (see Batty and Kerrigan 2018). For some researchers, the act of practice (making/doing) is a research method which then relies on reflecting on that practice-method to reveal the contribution, usually about what they discovered about their practice during the process. Here we are concerned with how theories and ideas are put forward in and through a creative work, where that work (e.g., comedy screenplay) actively performs the research findings - its core DNA emerging from research. To map what this looks like in a comedy screenwriting practice, let us first consider role of fiction in academic research more broadly.

\section{Fiction as/in Research}

Paul Williams celebrates the use of 'fictional devices in order to explore issues that are traditionally articulated by conventional forms of critical analysis' and advocates the imagined content of fiction 'as an alternative form of academic discourse to the conventional essay' (Williams 2013, p. 250). Pointing out how 'the richness of fictional discourse compared to conventional literary criticism creates layers of complexity that mirror [the] subject matter' (Williams 2013, p. 253), this highlights the potential of fiction, with its infinite possibilities of both content and style, to not only embody or perform research findings (see Haseman 2006), but also to engage readers in a conversation about the research topic (see also Batty and Baker 2018a). 
Marsha Berry (2016) uses this method in her ethnographic study of smartphone camera users, in which she presents a series of fictionalised vignettes drawn from her data that not only mirror the 'creative vernaculars' discovered of her users, but that also 'enhance' the very practice of ethnographic research through combining observation and analysis with creative writing.

Narrative enquiry as a research method is well documented in areas such as education, social work and the medical professions (see Johns 2006; Clandinin and Connelly 2000), often as a way of 'enhancing' reflective practice for greater understanding and subsequent application back in the workplace (see Moon 2004). While there are clear similarities with a narrative enquiry approach, fiction as method (specifically in our case, comedy screenwriting as method) supposes the act of creating an imagined, comedic world as being central to the project, not an offshoot of it. Where the research question asks something of fiction itself, then fiction becomes a methodology wherein iterative processes, such as those enacted by fiction writer/researchers, see them return to their (research) practice 'again and again to reposition and remap their "conceptual terrain" more precisely over time' (Boyd 2010, p. 139). Thus, the methods inform a methodology that is 'necessarily emergent and subject to repeated adjustment, rather than remaining fixed throughout the process of enquiry' (Barrett 2009, p. 6, emphasis in original). Fiction as method also aligns with Scott Stroud's (2008) argument that a literary narrative (interpreted here as fiction) 'holds the power to move individuals to thought, reflection, action, and belief' (2008, p. 1), possessing cognitive qualities that allow for subjective perspectives to be experienced. In short, fictional narratives enable theories and ideas to be shown and felt (to know tacitly), not merely told (to comprehend).

In relation to scriptwriting broadly, Dallas Baker (2013) discusses its potential as a research artefact in the academy, drawing on narrative components such as form, structure and theme to test and disseminate ideas in innovative ways. In a follow-up article, Baker, Batty, Beattie and Davis posit that 'scripts can and should be treated as research outcomes, and that scriptwriting itself, in the right context, can be seen as a legitimate and important research practice' (Baker et al. 2015, p. 8). More recently, another article discusses the role of fiction in screenwriting research specifically, with a focus on narrative affect (Batty and Baker 2018b). Across the three special issues of TEXT: Journal of Writing and Writing Courses in which these script discussions take 
place, six screenplays use comedy specifically to 'do' research, five of which are written by the authors of this article, and three of which will be discussed below.

As researchers working with artefacts intended for the screen, it is useful to look at screen production research practices more broadly. For Margot Nash, an Australian filmmaker and screenwriter, research determines the way she works with material for the screen; she is open and imaginative in order that narrative components lead her practice: 'Rather than following a predetermined shape, I try to let structure emerge out of the material and be a response to the ideas' (2014, p. 97). Speaking of fiction screenplays specifically, British screenwriter and academic Helen Jacey believes that writers not only have something to say, they also serve a crucial role in society's representation of itself: 'a first step screenwriters might usefully take is to define their authorial intentions and what might largely be termed as their “subjective value system"' (2014, p. 241). Such a 'subjective value system', as portrayed through fictional means, functions to probe, explore, expose and test out propositions about the world, which encourage audiences to think. Writing about queer screen practitioners who use the space of fiction to challenge norms and selfrepresent, Christopher Pullen purports: 'Whether directly or indirectly, screenwriters write about themselves; or at the very least, they frame their personal ideas, contexts and skills in the mediation of a narrative' (2014, p. 285).

Shaun Kimber uses the genre of horror to understand how critical approaches can inform screenwriting practice, using research to enhance and move the genre forward from derivative to innovative. Using theory 'as a way of getting to the sinister heart of the story [you] want to tell' (Kimber 2014, p. 49), critical ideas are not in addition to, but rather complement practice, enabling screenwriters to use the fictional worlds they create to both refer to and transgress horror histories:

horror storytelling is enriched through an alignment of a well-researched knowledge of horror industries and audiences, the creative application of craft skills and techniques, and the imaginative understanding of conceptual and theoretical approaches to horror', which ultimately inspires horror screenwriters 'to further re-animate horror storytelling through the creative blending of theory and practice (Kimber 2014, p. 61).

If 'the creative intellect of horror screenwriters can be reanimated through the meaningful and constructive alignment of these intersecting practical and theoretical contexts' (Kimber 2014, p. 46), then a new type of script development practice emerges (see Batty et al. 2016). Nash calls this 'stepping into the unknown', an 
instincts-based critical practice that involves 'reading, thinking, dreaming and debating with others; exploring the known world first and then heading out into the unknown to hunt and gather images, sounds and ideas' (2014, p. 97). For Jacey, writing on the bromance story type, academic research that is directed towards creative practice can 'help screenwriters consider men from new critical angles, ones that can help them in their creation of male characters' $(2014$, p. 238). Theory and fiction can thus be brought together 'to understand ways that screenwriters might approach male character development' (Jacey 2014, p. 238). For Marilyn Tofler, reflecting on her practice-based $\mathrm{PhD}$, 'methods of screenwriting useful for the creation of social satire, featuring a female protagonist' (2014, p. 256) were developed from drawing on a rich history of satirical comedy theory and practice, including textual analysis of the Nancy Meyers film, Something's Gotta Give (2003); and according to Christopher Pullen, 'screenwriters have involved themselves in the process of self-representation, evident in their screenplays and cultural disseminations', which involves them 'speaking to mainstream audiences about the context of their identity' and 'involves a personal intimate subjectivity' (2014, p. 271).

As this overview of literature reveals, fiction occupies a special place in the academy and wider culture as a mode through which theories and ideas of various types can be illuminated, tested out and, in some cases, transgressed. Screenwriters, often working as individual agents in the larger continuum of screen production, might thus be considered intercessors of thought: they draw on theories, ideas and issues as vital fuel for their narratives, and then use their screenplay craft to shape and deliver fictional stories that attempt to activate those theories, ideas and issues in others.

\section{Comedy as/in Research}

Direct links can be made here with the comedy screenplay, which, when written under academic research conditions, also serves to probe, explore, expose and test out research questions or propositions (see Batty and Berry 2016; Batty et al. 2015; Lee et al. 2016). Functioning as 'a vital incubator for risk taking, reflexivity and fearless critical thinking' (Batty and Berry 2016, p. 182), creative practice research asks writers in the academy 'to bring multidisciplinary perspectives and creative research strategies to bear on issues and possibilities, and often to think outside the existing 
boxes' (Cherry and Higgs 2011, p. 13). As comedy screenwriters and academics, we use our craft to question, pull apart, test and offer deeper and/or alternative modes of writing for the screen, considering aspects such as structure, theme, character, visual grammar and dialogue. Being in the academy asks us to position ourselves as researchers first and foremost (Knudsen 2016); thus, we use screenwriting - and here, comedy screenwriting - as an explicit research method within a broader creative practice research methodology.

Previous decades of comedy scholarship have lamented the 'historical bias against a close and serious consideration of comedy' (Horton 1991, p. 2), as evidenced by 'a long history of criticism that has viewed comedy as inferior to other genres in Western culture' (Horton 1991, p. 2). As Geoff King has noted, comedy is rarely considered 'prestigious or award-winning [and is] often subject to critical neglect' (2002, p. 1). While it is true that comedy is becoming a serious mode for critical study - as evidenced, for example, by the work of Sharon Lockyer and Brett Mills - what of comedy writing practice as research? There are some examples, such as practice-based screenwriting PhDs by Benjamin Law (2009) and Suya Lee (2016), which use comedy to investigate (respectively) representations of Asian-Australians on screen, and the evolving genre of farce. But in an era of strong growth in creative practice research, how might comedy screenwriting evolve as a contributing method?

One way to think about comedy writing and research is the lens through which the narrative is structured: story, theme, character and so on. Specifically, and as will be explore further below with reference to Taylor's $\mathrm{PhD}$, the notion of perspective is useful due to its inherent sense of intention; in research terms, the critical enquiry it seeks. As Taylor discussed in her PhD by creative practice - specifically, by comedy screenplay - 'intrinsic to [certain] scripted mechanics is the knowledge that comedy and perspective are already inherently linked, in terms of the question 'who sees?' (2016, p. 191). Comedy consultant and author Steve Kaplan writes, 'Comedy exists in the eye - the rods and cones - of your character. What they see and what they know' (2013, p. 29). What characters 'know', then, as underpinned by research, brings to bear research intentions in a script. Likewise, Taylor explored through practice how 'Comedy tends to involve departures [...] from what are considered to be the “normal" routines of life of the social group in question' (King 2002, p. 5), thus actively pursuing a research enquiry through perspective, using structural techniques and the world of a story to contest, for example, social, political and cultural norms. 
These examples outline but two potential approaches to comedy through creative practice.

What we do in the remainder of this article, then, is draw on some of our own comedy writing research outputs to discuss the ways in which researchers might present their findings in imaginative, innovative and fun ways that can expand understanding; and, given their non-traditional academic form, that might garner high levels of engagement that could then lead to impact. We outline how comedy as method offers a way to think through the screenplay (Batty et al., 2016), where its various narrative components - however slapstick, screwball, dark, lampooning or otherwise - 'do' research. The choice of these published works, rather than produced screen works we have participated in, is primarily because the screenplays can be accessed by those wishing to read them, and also because they were written and framed specifically as research artefacts within the Australian university system. Each screenplay was published with an accompanying research statement, articulating the background, contribution and significance of the work as would be evident in a traditional research output such as a journal article.

\section{Frankie Goes to Hollywood}

Based on a published book chapter Batty about the use of character (as opposed to subject) in non-fiction screen texts, the primary area of interest to him when developing the parody screenplay, Frankie Goes to Hollywood (2013), was theories of story structure and the character arc. He wanted to critique how situations and people are manipulated for entertainment, and in relation to character Frankie's trip to Hollywood and her encounter with screenwriting gurus (bear in mind that Batty also writes screenwriting books, so there is another level of critique here), how real scenarios are scripted - or 'story produced' - to the extent that they are no longer real. Instead, they are carefully plotted in an Aristotelian sense - oozing with pity, fear and catharsis - and where there is no plot, unethical interventions are made.

The screenplay parodies the world of reality television and is built on the premise of mainstream broadcasters manipulating people and situations for the sake of 'good entertainment' - and ratings. To highlight these practices through comedy, the work uses the setting of a 'quality' production company that is thrown into turmoil when executive producer Frankie returns from a trip to Hollywood, and 
desperately attempts to change her team from being ethical storytellers to 'hack' producers who create high drama that will appeal to the masses. A take on the 'fish out of water' narrative trope, the script employs a purposeful - some might call 'high camp' - structure that in itself parodies the story shapes used in (some) reality television: melodrama, clichéd scene cliff-hangers, climactic montage, and so on. Featured in the cast of characters is Hollywood actor Chris Hemsworth, who is offered an honorary $\mathrm{PhD}$ in return for narrating the series.

The opening sequence intercuts scenes of producer Adam and assistant Joseph debating the moral nature of a new show they are creating, with the return of Frankie - fresh from Hollywood - who has some new ideas for her team. While Adam and Joseph discuss Lord Reith's values, to inform, education and entertain, Frankie glides through the building with a simple aim: 'Pile them high and sell it cheap!' (p. 3). She tells Adam and Joseph that she wants misfits - and lots of them (p. 4) - and encourages them to 'smell the conflict' (p. 5) in the screenwriting books she has brought back with her.

As Frankie's reign continues, Adam slides into depression. He makes shows about gardens and real people, not celebrity-wannabes and fake scenarios. Auditions for the new show attract desperate families, thugs, the mentally impaired - even the dead - and under Frankie's gleeful watch we see the manipulation of real-life situations to make good drama. Real scenarios are shot, shot again, and then shot again, just to get the right amount of conflict and sleaze. There are allusions to affairs, cross-dressing, kleptomania and abuse - all in the name of improved ratings. Adam complains to Frankie, asking her if she has any ethics, but all she cares about is getting 'a television first' (p. 26).

In the end, Frankie wins and Adam decides to move into children's television. While Frankie sees this as 'small ideas for small minds' (p. 28), Adam cannot imagine a life where he uses people (at best) in order to improve ratings. The show, My Family Rules! is a success before its even aired, and clearly for Frankie, things are only going to get better - even of for the participants, things can only get worse.

Unexpectedly, the research undertaken for the book chapter also influenced the use of voice in the script: both a general story voice, as written into the screen directions to add tone, texture and perspective; and character dialogue. On the former, the overarching story voice tries to reflect the intensity of the drama being espoused by Frankie; or, on a meta level, the voice of the discourse surrounding how reality 
television manipulates situations for dramatic value. The literature on reality television, which includes guides for how creators can work in the genre (e.g., Thirkell 2010), notes the ways in which it purposely creates clashing ideals and sensibilities, and is often driven by a sense of impending danger or catastrophe. Thus, Frankie Goes to Hollywood employs a dark comedic voice that emulates this tone, while at the same time saying something about it. It is corporate and tight, hungry and go-getting, as if straight out of a trashy screenwriting book. The satirical voice draws deep attention to the ethically dubious practices of the television world being explored.

On the latter, quotations Batty used in the book chapter - from both academics and reality television creators and producers - became the basis for particular lines of dialogue to emphasise the parodic nature of the work: the rhetoric of Frankie and her protégé assistant, Romeo, hell bent on producing an award-winning show; and the concern of producer Adam, who was trained on Reithian values and whose awardwinning career is premised on grass and flowers, not dragging people out of psychiatric units.

Examples from Frankie include:

I want misfits - and lots of them! Bogans and bridezillas, all under one roof. Preferably one that's leaking. (p. 4)

We hit them with conflict and character. No more of this, 'Oh, aren't they lovely people?' garbage. From now on, drama, drama, drama. Tectonic plates clashing under the fault lines. (Beat.) Boys, we're going to rock this nation to its core! (p.6)

People go to school to be educated. And read newspapers to be informed. They turn on the TV to be entertained. (p. 10)

Then we slam into the kids coming home from school. Music lessons intercut with Home and Away. Theme tune to show the contrast. Beethoven's 5th with 'You know we belong together'. (p. 12)

We end with a marriage. Spouses from different families. (Beat.) Divorce with a capital 'Holy shit!' We do a one-hour special. (p. 20)

In stark contrast to other moments and characters in the screenplay, and in line with Romeo, whose dialogue becomes more like Frankie's after she employs him as her personal assistant, these examples of story voice and character dialogue can be understood as modes of comedy practice that emerged specifically from research. The 


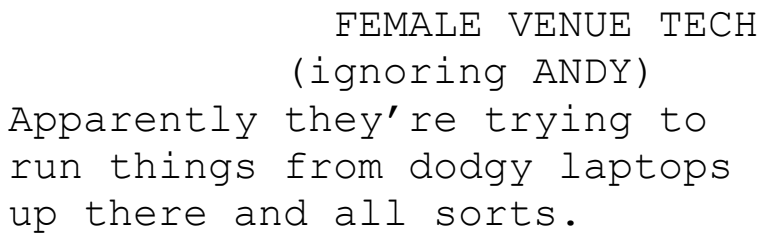

General confusion and battle of wills as -

FADE TO

BLACK

OVER BLACK:

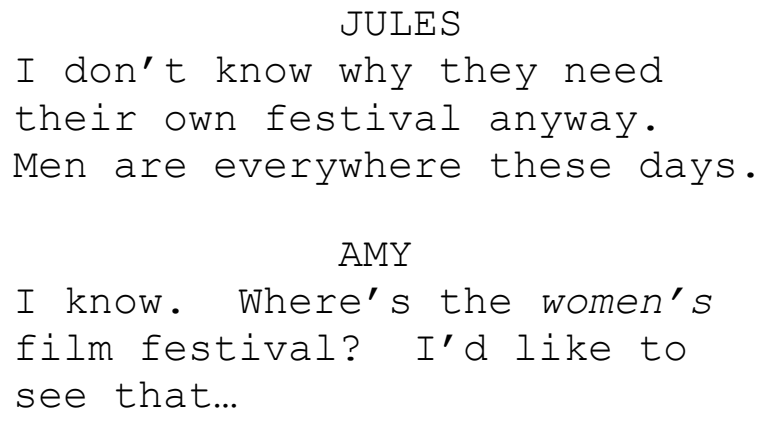

\section{END OF SCRIPT}

With Power Cut serving to help Taylor explore the device in its own right, she could then work to overcome such limitations in her $\mathrm{PhD}$ screenplay, and how to deliberately position her protagonist as a misfit within the narrative. Unlike the world of Mounting the Men's Film Festival, which exists as if it were the default world, the $\mathrm{PhD}$ screenplay, being a feature length screenplay, was able to establish the protagonist within the default world in the first sequence, before transporting her to the flipped reality. In this way, though she finds herself at the top of the hierarchy, at least in gendered terms, she is nonetheless a misfit, in terms of not knowing the rules. 
In both the cases of Funny/Peculiar and Power Cut, the research enquiry hinged on experiments with perspective. As John Vorhaus points out, a comic perspective is 'a character's unique way of looking at the world, which differs in a clear and substantial way from the "normal" world view' (1994, p. 31). Thus, the craft of writing comedy intersects with the research enquiry, and the findings lie in the nexus.

\section{The (Im)Perfect Screenplay}

As an extension of his interests in meta-narratives that interrogate the craft of screenwriting and its surrounding industries - both the screen industry and the academy (see Batty 2018) - Batty decided to use the genre of television soap opera to test the limits of what we understand as 'good' and 'bad' screenwriting. The (Im)Perfect Screenplay: A Parody of Craft and Industry (Batty 2015), aimed to expose the fundamental techniques required to write 'successfully' for the genre. While the script is deliberately funny, the speculative soap opera episode within the script is generally not supposed to be funny; rather, comedy is used as a method to 'prod' its audience/reader in regard to the genre's somewhat clichéd tropes and expectations, and goad them into considering how much they know tacitly about screenwriting craft, even if they have never studied it. As the abstract highlighted, the script 'draws attention to formulaic conventions and the industry in which they operate' and 'deliberately exploits craft and convention to the extreme', in doing so offering 'simultaneously a perfect and an imperfect screenplay' (Batty 2015, p. 1).

Character types and the melodramatic relationships they encounter were central to the work, as a lens through which to see, hear and feel 'good' and 'bad' screenwriting. Previously, Batty has researched the soap opera form and through publications, have made connections between soap and reality television. This theoretical background allowed him to play in the creative practice space with ideas of character and form, and gain pleasure from creating characters that literally and figuratively speak about the genre.

An example of research-led comedy practice in this work includes setting up plot development via signposting story beats, which then go nowhere. In the following example, married couple Alan and Sylvie share kind words and affectionate looks, all the while Alan digging a hole. The dramatic question set here would be: why is he digging the hole? 
4. EXT. GARDEN - MORNING (pp. 3-4)

A spade slams into the ground and pulls away a lump of earth. This is the work of ALAN (late 60s), a man with more time on his hands than he cares to think about.

Alan slams the spade in again, determination in his eyes. His wife of forty years, SYLVIE (late 60s), comes out in a floral apron. She has a mug of steaming hot tea for Alan.

$$
\begin{gathered}
\text { ALAN } \\
\text { You're a darl. } \\
\text { S knowie }
\end{gathered}
$$

Alan takes the tea from Sylvie and takes a sip, savouring the taste. His eyes close with pleasure.

$$
\text { SYLVIE }
$$

How's it all going?

ALAN

A lot of turning, but it's starting to look good.

SYLVIE

Smells good, too.

ALAN

The smell of life.

They both sigh at the same time - and gaze at the garden for a moment.

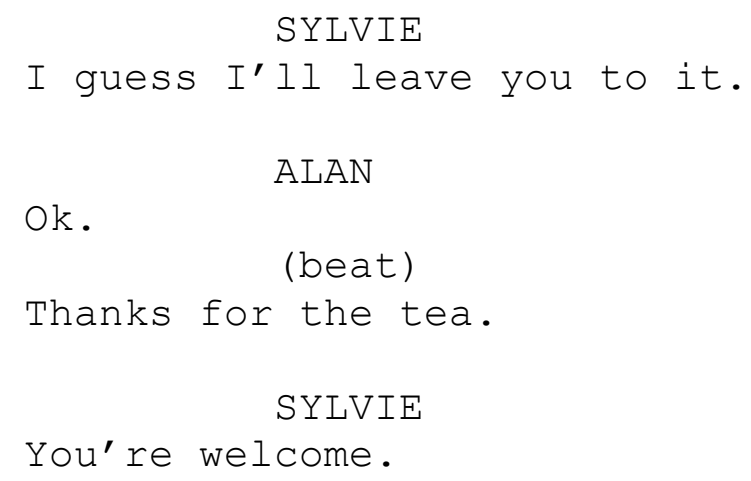


Alan puts the tea down and continues to dig, determined.

The digging continues, but as explicated in the screen directions, there are clear hints that narrative progression has stalled. A typical question asked of a scene would be: what is its function? In this screenplay, Batty draws attention to this question by clearly signalling that nothing has moved on. In actual fact, Sylvie's line 'It's coming on well', which might be spoken had he actually achieved something, was a device to emphasise this point.

8. EXT. GARDEN - AFTERNOON (pp. 8-9)

Alan is still digging. The hole doesn't seem to have changed much since the last time.

Sylvie comes out with another mug of tea, this time wearing a different floral apron.

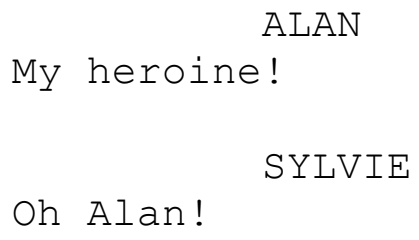

She passes him the tea. He takes a sip as Sylvie looks at the garden.

\section{ALAN}

It's coming on well.

Looks like it.

They both sigh at the same time.

SYLVIE

I'll leave you to it then.

ALAN

Thanks, darl.

SYLVIE

Play your cards right and I'll bring

you a tea later.

ALAN

What would I do without you, hey? 
Sylvie smiles as she heads back to the house. She glances back before she steps inside.

Alan continues to dig.

The parody continues when, rather than there being a reveal as to the purpose of the recurring action, it is reversed to the point that it is clear the point being made was that nothing had happened; there was no narrative drive.

14. EXT. GARDEN - EARLY EVENING (p. 15)

Alan still digs, but the hole is now not a hole - he's filling it back up.

Sylvie appears behind him with another mug of tea, wearing yet another floral apron.

He gives her a peck on the cheek as she passes him the mug •

Sylvie heads back to the house, but stops. She turns.

SYLVIE

It's starting to get dark.

ALAN

That it is.

Sylvie heads back into the house. Alan looks at the 'hole'.

Another example is the use of exaggerated and heightened dialogue to expose the vital soap practice of providing new and returning audiences with story exposition. While this is typically obvious yet somewhat 'massaged' into soap dialogue, here it was purposefully impossible and nonsensical in order to draw attention to the device. This was particularly the case in the scenes set in the pub, where, as in soap plotting practice, a set of character arcs were at play.

10. INT. PUB - AFTERNOON (p. 10)

A group of people sit in a booth, laughing hysterically. DREW (30s, always on edge) walks into the middle of it all.

MARY (60s, battle-axe) clearly seems to be in charge. 
MARY

You just wouldn't credit it!

DREW

What's going on?

ROBERTA (40s, wet as water) pipes up.

ROBERTA

And when she said that she wouldn't

... and then he said that he would ...

ANGELA (50s, village idiot) has an unfortunate verbal quirk.

ANGELA

Spam!

DREW is trying to make sense of it all.

MARY

And they both did it anyway!

Everyone laughs again, this time even more knowingly.

\section{DREW}

Who are we talking about?

MARY

You really had to be there.

This continued to grow, from the sublime to the ridiculous, as the scene was returned to again and again. For example:

12. INT. PUB - AFTERNOON (p. 12)

The people in the booth are still laughing. Drew now looks impatient - if not a little paranoid.

MARY

And then when she said that about

the sock drawer!

ROBERTA

I never did understand peep-toe sandals. Especially in the context of what she then told him her dad had done with the shoe buffer when they went on a long-haul family holiday in 1987. 
Arguably, while the use of parody, cliché and over-scripting of dialogue is intended to draw attention to the craft techniques at play, in some cases it might not be all that different from how an episode is actually scripted. For some soap operas, it is widely felt that, over time, they become parodies of themselves.

\section{Conclusion}

As these examples begin to demonstrate, creative practice research - and screenwriting in particular - can benefit from comedy as method by virtue of the way it can re-imagine and re-define knowledge in a mode that both represents and draws attention to its very DNA. Conceived creatively from the outset, a comedy-driven approach to research has enabled us to explore, question, test and probe ideas and concepts in fresh, comic ways. Comedy thus operates on both a functional and philosophical level: it does the job it needs to in a way that is recognisable (i.e., in scripted form); and it responds creatively and with nuance to find ways of performing the research sitting at the core of its making (i.e., method). As the literature reviewed tells us, screenwriting practitioners use a variety of narrative devices to encourage their audiences to think. They draw on histories, social issues, cultural concerns, writing tools and paradigms, and industry contexts.

Further, we wish to suggest that within the broader notion of 'fiction as method', comedy is an approach in which strategies specific to its form are deployed for enacting research through creative practice. That is to say, while comedy is a mode of fiction, it comes with its own frameworks, affordances and challenges. For instance, a common convention in comedy is that of the naïve protagonist - one that is oblivious to their own shortcomings and deficiencies, to the situation they find themselves in, issues with other characters, and so on. As Jacey believes, 'Comedy is derived from the heroine's blind spot, which generates a lot of internal and external complications' (2010b, p. 171). Therefore, it follows that in comedy screenwriting research, as evidenced in these case studies, sometimes an unawareness of the 'research problem' can be seen to reside in the protagonist. If the screenplay embodies research findings through its very fabric, then whereas story and world might 'know' these aspects and purposely allude to them, the protagonist, conversely, does not know. Perhaps this is a hallmark of comedy as research method: unlike in research-based fiction, where the protagonist is usually created to represent a 
conscious awareness of the questions driving the project, in comedy it is the not knowing of these underpinning questions that is important. The relationship between protagonist and audience, then, is potentially a unique and useful aspect of comedy research, whereby the knowledge gaps of the protagonist serve to illuminate the theoretical concerns for the audience. In other words, the tools of comedy can be used to draw attention to theories, ideas and contexts; to critique and offer alternative readings and positions; and to make audiences/readers think about their own knowledge, including from where it originates.

As this article has outlined, the writing and making of fiction is emerging strongly as a legitimate method for producing research in the academy; and we suggest it is timely to examine the different modes, forms and genre within fiction in order to explore their unique affordances and contributions to creative practice research. It is in this spirit that we suggest 'comedy-as-method' is a discrete mode of research enquiry that has the same potential as comedy itself: to accept and celebrate the shortcomings of humanity by illuminating the inevitable 'knowledge gaps' towards seeking the answers together.

\section{List of references}

Baker, Dallas. 2013. 'Scriptwriting as Creative Writing Research: A Preface.' TEXT: Journal of Writing and Writing Courses, special issue 19, 1-8, available at: http://www.textjournal.com.au/speciss/issue19/Baker_preface.pdf [accessed January 22 2016].

Baker, Dallas, Craig Batty, Debra Beattie and Susan Davis. 2015. 'Scriptwriting as a Research Practice: Expanding the Field.' TEXT: Journal of Writing and Writing Courses, special issue 29, 1-8, available at:

http://www.textjournal.com.au/speciss/issue29/content.htm [accessed January 22 2016].

Barrett, Estelle. 2009. 'Introduction', in E Barrett \& B Bolt (eds), Practice as Research: Approaches to Creative Arts Enquiry, I. B. Tauris, London \& New York, pp. 1-13. 
Batty, Craig. 2013. 'Frankie Goes to Hollywood: A Screenplay.' TEXT: Journal of Writing and Writing Courses, special issue 19, 1-35, available at:

http://www.textjournal.com.au/speciss/issue19/content.htm [accessed April 22 2016].

Batty, Craig. 2015. 'The (Im)Perfect Screenplay: A Parody of Craft and Industry.' TEXT: Journal of Writing and Writing Courses, special issue 30, 1-18, available at: http://www.textjournal.com.au/speciss/issue30/content.htm [accessed April 22 2016].

Batty, Craig. 2018. 'A Vacuous Screenplay in Search of Rigour.' TEXT: Journal of Writing and Writing Courses, special issue 48, 1-18, available at:

http://www.textjournal.com.au/speciss/issue48/content.htm [accessed April 30 2018].

Batty, Craig and Dallas Baker. 2018a. Screenwriting as a Mode of Research, and the Screenplay as a Research Artefact. In: Craig Batty and Susan Kerrigan (eds.). Screen Production Research: Creative Practice as a Mode of Enquiry. Basingstoke: Palgrave Macmillan, 67-84.

Batty, Craig and Dallas Baker. 2018b. 'The Role of Fiction in Screenwriting (as) Research.' TEXT: Journal of Writing and Writing Courses, special issue 48, 1-10, available at: http://www.textjournal.com.au/speciss/issue48/content.htm [accessed May 3 2018].

Batty, Craig, Louise Sawtell and Stayci Taylor. 2016. 'Thinking Through the Screenplay: The Academy as a Site for Research-Based Script Development'. Journal of Writing in Creative Practice, 9(1-2), 149-162.

Batty, Craig and Marsha Berry. 2016. 'Constellations and Connections: The Playful Space of the Creative Practice Research Degree.' Journal of Media Practice, 16(3), 181-194.

Batty, Craig, Sung-Ju Suya Lee, Louise Sawtell, Stephen Sculley and Stayci Taylor. 2015. 'Rewriting, Remaking and Rediscovering Screenwriting Practice: When the Screenwriter Becomes Practitioner-Researcher.' In: Writing the Ghost Train Refereed Proceedings of the $20^{\text {th }}$ Conference of the Australasian Association of 
Writing Programs, 2015, 1-16, available at:

http://www.aawp.org.au/publications/writing-the-ghost-train-rewriting-remakingrediscovering/ [accessed April 22 2016].

Batty, Craig and Susan Kerrigan (eds.). 2018. Screen Production Research: Creative Practice as a Mode of Enquiry. Basingstoke: Palgrave Macmillan.

Berry, Marsha. 2016. 'Out in the Open: Locating New Vernacular Practices with Smartphone Cameras.' Studies in Australasian Cinema, 10(1), 53-64.

Boyd, Nicola Mary. 2010. 'Strange Loops and Confessions: In search of a Creative Writing Research Methodology', PhD thesis, Griffith University.

Cherry, Nita and Joy Higgs. 2011. 'Researching in Wicked Practice Spaces: Artistry as a Way of Researching the Unknown in Practice.' In: Joy Higgs, Angie Titchen, Debbie Horsfall and Donna Bridges (eds.). Creative Spaces for Qualitative Researching: Living Research. Rotterdam: Sense Publishers, 13-22.

Clandinin, D. Jean and F. Michael Connelly. 2000. Narrative Inquiry: Experience and Story in Qualitative Research. San Francisco, CA: Jossey-Bass Publishers.

Giglio, Keith. 2012. Writing the Comedy Blockbuster: The Inappropriate Goal, 1st edn. Studio City, CA: Michael Wiese Productions.

Haseman, Brad. 2006. 'A Manifesto for Performative Research.' Media International Australia, Incorporating Culture \& Policy, (118), 98-106.

Jacey, Helen. 2014. 'And the Screenwriter Created Man: Male Characterisation in Bromance and Bromedy.' In: Craig Batty (ed.). Screenwriters and Screenwriting: Putting Practice into Context. Basingstoke: Palgrave Macmillan, 238-255.

Johns, Christopher. 2006. Engaging Reflection in Practice: A Narrative Approach. Oxford: Blackwell. 
Kaplan, Steve. (2013). The Hidden Tools of Comedy: The Serious Business of Being Funny, Studio City, CA: Michael Wiese Productions,

Kimber, Shaun. 2014. 'Horror Screenwriting: Blending Theory with Practice.' In:

Craig Batty (ed.). Screenwriters and Screenwriting: Putting Practice into Context.

Basingstoke: Palgrave Macmillan, 46-65.

King, Geoff. 2002. Film Comedy, Wallflower Press, London.

Knudsen, Erik. 2016. 'Journal of Media Practice: A Few Thoughts from the Incoming Chair of the Editorial Board.' Journal of Media Practice, 16(3), 179-180.

Law, Benjamin. 2009. 'The New Lows: Representing Asian-Australians on Television', PhD thesis, Queensland University of Technology.

Lee, Sung-Ju Suya, Anne-Marie Lomdahl, Louise Sawtell, Stephen Sculley and Stayci Taylor. 2016. 'Screenwriting and the Higher Degree by Research: Writing a Screenplay for a Creative Practice PhD.' New Writing: The International Journal for the Practice and Theory of Creative Writing, 13(1), 85-97.

Lee, Sung-Ju Suya. 2016. "“The Wedding Jackpot”: A Critical and Creative Investigation of the Farce Genre in the Context of Screenwriting and Feature Film', $\mathrm{PhD}$ thesis, RMIT University.

Macdonald, Ian W. 2010. 'So it's not Surprising I'm Neurotic: The Screenwriter and the Screen Idea Work Group.' Journal of Screenwriting, 1(1), 45-58.

Mizejewski, Linda. 2014. Pretty/Funny, 1st edn, University of Texas Press, Austin.

Moon, Jennifer. 2004. A Handbook of Reflective and Experiential Learning. London: Routledge-Falmer. 
Nash, Margot. 2014. 'Developing the Screenplay: Stepping into the Unknown.' In: Craig Batty (ed.). Screenwriters and Screenwriting: Putting Practice into Context. Basingstoke: Palgrave Macmillan, 97-112.

Pullen, Christopher. 2014. 'Self-Reflexive Screenwriting and LGBT Identity: Framing and Indirectly Reading the Self.' In: Craig Batty (ed.). Screenwriters and Screenwriting: Putting Practice into Context. Basingstoke: Palgrave Macmillan, 271287.

Smith, Hazel and Dean, Roger. 2009. Practice-led Research, Research-led Practice in the Creative Arts. Edinburgh: Edinburgh University Press.

Stroud, Scott R. 2008. 'Simulation, Subjective Knowledge, and the Cognitive Value of Literary Narrative.' The Journal of Aesthetic Education, 42(3), 19-41.

Taylor, Stayci. 2017. 'Screenwriting Melbourne/s: The Challenges of Re-presenting and Re-creating Melbourne Within a Screenplay's Flipped-Reality Narrative', Senses of Cinema no. 85 <http://sensesofcinema.com/2017/screeningmelbourne/screenwriting-melbourne-s-challenges-re-presenting-re-creatingmelbourne-within-screenplays-flipped-reality-narrative/> (no page numbers)

Taylor, Stayci. 2016. 'In Her Shoes: flipped-realities and female perspectives in comedy screenwriting', Senses of Cinema no. 80 $<$ http://sensesofcinema.com/2016/new-directions/in-her-shoes-flipped-realities-andfemale-perspectives-in-comedy-screenwriting/>

Taylor, Stayci. 2015. 'Mounting the Men's film festival: a mockumentary web series webisode 1: Power Cut', TEXT: Journal of Writing and Writing Courses, no. Special Issue 29: scriptwriting as creative writing research II, pp. 1-15.

Taylor, Stayci. 2014. 'The Model Screenwriter: A Comedy Case Study', Minding the Gap: Writing Across Thresholds and Fault Lines - the Refereed Proceedings of the 19th Conference of the Australasian Association of Writing Programs, 2014, pp. 1-20. 
Tofler, Marilyn. 2014. 'Gals Who Make the Jokes: Feature Film Screenwriting foriseptithe Satirical Female Voice.' In: Craig Batty (ed.). Screenwriters and Screenwriting: Putting Practice into Context. Basingstoke: Palgrave Macmillan, 256270.

Thirkell, Robert 2010 Conflict: An Insider's Guide to Storytelling in Factual/Reality TV and Film, London: Methuen

Vorhaus, John. (1994). The Comic Toolbox: How to Be Funny Even If You're Not, St. Leonards, N.S.W: Allen \& Unwin

Williams, Paul. 2013. 'Creative Praxis as a Form of Academic Discourse'. New Writing: The International Journal for the Practice and Theory of Creative Writing, 10(3), 250-260. 